\title{
PENERAPAN METODE PROBLEM SOLVING TERHADAP KEMAMPUAN BERPIKIR KRITIS PESERTA DIDIK DI SMA NEGERI 3 MAKASSAR
}

\author{
Marzuki* \\ Universitas Negeri Makassar \\ Marzukineutron@gmail.com
}

\author{
Aisyah Azis \\ Universitas Negeri Makassar \\ aisyahazis@unm.ac.id \\ Salamang Salmiah Sari \\ Universitas Negeri Makassar \\ salmiahsari@unm.ac.id \\ *koresponden author
}

Abstrak - Penelitian ini adalah penelitian eksperimen semu yang bertujuan untuk menerapkan metode problem solving terhadap kemampuan berpikir kritis peserta didik SMAN 3 Makassar. Variabel bebas dalam penelitian ini adalah pembelajaran dengan dimensi metode problem solving dan konvensional, sedangkan variable terikatnya adalah kemampuan berpikir kritis. Populasi dalam penelitian ini adalah seluruh kelas XI IPA SMAN 3 Makassar kecuali peserta didik di kelas unggulan. Teknik sampling yang digunakan dalam penelitian ini adalah purposive sampling yang kemudian sampel yang dipilih adalah kelas XI IPA 3 sebagai kelas eksperimen dengan jumlah siswa 38 orang dan kelas XI IPA 7 sebagai kelas kontrol dengan jumlah siswa 32 orang. Hasil penelitian menunjukkan bahwa skor kemampuan berpikir kritis pada kelas eksperimen dan kelas kontrol adalah 7,24 dan 5,19 dengan standar deviasinya masing-masing sebesar 1,84 dan 1,99. Hasil analisis inferensial bahwa terdapat perbedaan yang signifikan terhadap kemampuan berpikir kritis peserta didik antara yang diajar dengan metode problem solving dengan yang diajar secara konvensional pada taraf signifikansi $\alpha=0,05$.

Kata Kunci : Problem Solving, kemampuan berfikir kritis

Abstract -. This study was semi-experimental research aiming to apply the problem solving method towards student's critical thinking ability in SMAN 3 Makassar. Learning with problem-solving method dimension was the free variable, while the bonded one was critical thinking ability. This study took whole students in that school as the population except they were in special class. The research used purposive sampling as the sample taking techniqule in which the XI IPA 3 class (38 pupils) was the experimental class, and XI IPA 7 class (32 students) was the control class. The research's result showed that the score of critical thinking skill in experimental class and control class was 7,2 and 5,2 respectively with deviation standard 1,8 and 2,0. The inferential analysis result depicted that there was a significant difference towards students' critical thinking skill between they thought by using problem solving method and they taught by conventional method at the significance level $\alpha=0,05$.

Keywords : Problem Solving, critical thinking ability. 


\section{A. PENDAHULUAN}

Kegiatan pembelajaran dalam pendidikan, khususnya pendidikan formal yang berlangsung di sekolah merupakan interaksi aktif antara pendidik dan peserta didik. Tugas dan tanggung-jawab utama seorang pendidik adalah mengelola pembelajaran yang efektif, dinamis, efisien dan kondusif. Hal ini dapat ditandai dengan adanya kesadaran dan keterlibatan aktif di antara dua subjek pembelajaran tersebut. Peserta didik diharapkan aktif dalam proses pembelajaran, sementara pendidik hanya sebagai fasilitator yang bertugas untuk membimbing dan mengarahkan peserta didik untuk mencapai tujuan pembelajaran.

Proses belajar mengajar (pembelajaran) adalah upaya secara sistematis yang dilakukan guru untuk mewujudkan proses pembelajaran berjalan secara efektif dan efisien yang dimulai dari perencanaan, pelaksanaan dan evaluasi (Rahmah, 2015). Menurut (Aminah, 2012), pembelajaran aktif merupakan suatu pembelajaran yang mengajak peserta didik untuk belajar secara aktif, karena dengan belajar secara aktif, merekalah yang mendominasi aktifitas pembelajaran, sehingga membuat mereka aktif menggunakan otak, baik untuk menemukan ide pokok dari materi, memecahkan persoalan, atau mengaplikasikan apa yang baru mereka pelajari ke dalam satu persoalan yang ada dalam kehidupan nyata.

Pada kurikulum 2013, menurut (Permendikbud, 2014), implementasi pendidikan di SMA yang selama ini lebih menekankan pada pengetahuan, perlu dikembangkan menjadi kurikulum yang menekankan pada proses pembangunan ranah sikap, pengetahuan dan keterampilan peserta didik melalui berbagai pendekatan yang mencerdaskan dan mendidik. Bentuk pembelajaran pada kompetensi dasar tersebut haruslah menggunakan pembelajaran yang aktif untuk menumbuhkan kemampuan keingintahuan peserta didik dalam menemukan hasil/konsep dari materi yang akan diajarkan.

Berdasarkan hasil observasi di SMA Negeri 3 Makassar, pembelajaran yang dilakukan di sekolah tersebut masih memusatkan pembelajaran pada pendidik sehingga peserta didik cenderung pasif dalam belajar karena hanya menerima setiap informasi yang diberikan pendidik dan kemudian dicatat begitu saja. Hal ini juga dapat membuat peserta didik kurang mampu dalam memahami materi yang diberikan dengan baik dan kesulitan dalam menyelesaikan permasalahan fisika yang diberikan. Apalagi fisika merupakan mata pelajaran yang didalamnya membutuhkan konsep dasar dan kemampuan matematis untuk menyelesaikan soal-soalnya.

Kemampuan berpikir memerlukan kemampuan mengingat dan memahami, olehnya itu kemampuan mengingat dan memahami adalah bagian terpenting dalam mengembangkan kemampuan berpikir. Artinya, siswa yang memiliki kemampuan mengingat dan memahami belum tentu memiliki kemampuan berpikir. Namun, siswa yang memiliki kemampuan berpikir sudah pasti memiliki kemampuan untuk mengingat dan memahami.

Dengan demikian metode konvensional dianggap kurang memberikan kesempatan kepada siswa untuk berpikir karena hanya cenderung untuk mengingat dan mencatat apa yang diajarkan saja. Untuk itu pendidik haruslah membuat atau menyiapkan suatu metode pembelajaran yang baik. Salah satu metode yang bisa menjadi solusi adalah metode problem solving.

Kemampuan berpikir tingkat tinggi akan terjadi ketika seseorang mengaitkan informasi baru dengan informasi yang dimilikinya dengan menghubung-hubungkannya serta mengembangkan 
informasi tersebut untuk mencapai tujuan tertentu atau pun untuk menemukan penyelesaian dari suatu keadaan yang sulit dipecahkan (Fajar, 2014).

Penerapan metode pembelajaran problem solving dapat memudahkan siswa dalam memahami suatu pembelajaran. Metode ini juga dapat meningkatkan aktivitas siswa selama proses pembelajaran. Adanya permasalahan (problem) yang diberikan akan mengajak siswa lebih aktif dalam berpikir dan menantangnya untuk berpikir kritis untuk memecahkan masalah tersebut (Yustina, 2015).

Secara umum, masalah diartikan sebagai kesulitan yang dihadapi oleh peserta didik dan harus diselesaikan secara objektif dan sistematis. Beberapa orang juga memahami masalah (problem) sebagai kesenjangan antara kenyataan dan harapan.

Metode pemecahan masalah adalah penggunaan metode dalam kegiatan pembelajaran dengan jalan melatih siswa menghadapi berbagai masalah, baik masalah pribadi atau perorangan, maupun masalah kelompok untuk dipecah sendiri atau secara bersama-sama (Hamiyah, 2014).

Metode Problem Solving atau juga sering disebut dengan metode pemecahan masalah yang merupakan suatu cara yang dapat merangsang seseorang untuk menganalisis dan melakukan sintesis dalam kesatuan struktur atau situasi dimana masalah itu berada, atas inisiatif sendiri. Metode ini menuntut kemampuan untuk dapat melihat sebab akibat atau relasi-relasi diantara berbagai data, sehingga dapat menemukan kunci pembuka masalahnya.

Metode pemecahan masalah (Problem Solving) adalah cara memberikan pengertian dengan menstimulasi anak didik untuk memperhatikan, menelaah dan berpikir tentang suatu masalah untuk selanjutnya menganalisis masalah tersebut sebagai upaya untuk memecahkan masalah. Metode Problem Solving (metode pemecahan masalah) bukan hanya sekedar metode mengajar, tetapi juga merupakan suatu metode berfikir, sebab dalam metode Problem Solving dapat menggunakan metodemetode lainnya yang dimulai dengan mencari data sampai pada menarik kesimpulan (Syofyan, 2016).

Berdasarkan pengertian di atas, maka dapat disimpulkan bahwa metode Problem Solving merupakan suatu metode pemecahan masalah yang menuntut peserta didik untuk dapat memecahkan berbagai masalah yang ada baik secara perorangan maupun secara kelompok. Metode Problem Solving dapat meningkatkan kemampuan berpikir kritis peserta didik. Karena dalam metode ini peserta didik dituntut untuk dapat memecahkan persoalan yang mereka hadapi. Proses pembelajarannya menekankan kepada proses mental peserta didik secara maksimal, bukan sekedar pembelajaran yang hanya menuntut peserta didik untuk sekedar mendengarkan dan mencatat saja, akan tetapi meghendaki aktivitas peserta didik dalam berpikir. Tujuan akhir yang ingin dicapai adalah kemampuan peserta didik dalam proses berpikir untuk memperoleh pengetahuan.

Sebagai salah satu tolak ukur dalam melaksanakan unit pendidikan nasional, kemampuan berpikir kritis bisa dilaksanakan di sekolah sesuai dengan kebutuhan dan karakeristik peserta didik. Agar implementasi berpikir kritis bisa berjalan dengan baik, seluruh warga skolah harus berperan penuh untuk lebih mengefektifkan keberhasilan dalam kemampuan berpikir kritis. Strategi belajar mengajar menggunakan ketrampilan berpikir kritis bisa diusulkan untuk mencapai tujuan yang lebih bermakna.

Dengan demikian, tujuan pengajaran berpikir kritis di sekolah akan lebih menekankan pada belajar mandiri dan kreatifitas yang bermuara pada perbaikan proses pendidikan di Indonesia. Proses mental yang lebih tinggi yang disebut berpikir terjadi di dalam otak. Pikiran terarah atau pikiran pemecahan masalah dianggap sebagai jenis pikiran yang paling tinggi. Bentuk pemikiran yang paling tinggi berkenaan dengan arti atau makna dan konsep dari sesuatu, sehingga lebih bersifat abstrak 
dibandingkan dengan hal-hal yang nyata. Berpikir tidak dapat digantikan oleh informasi, sebaliknya, teknologi informasi dan komunikasi dapat membantu "berpikir". Kita perlu berpikir agar dapat menggunakan informasi yang kita miliki sebaik-baiknya, jika informasi yang kita peroleh tidak lengkap (Tawil, 2013).

\section{B. METODE PENELITIAN}

Jenis penelitian yang dilakukan adalah quasi experiment. Subjek penelitian adalah peserta didik kelas XI IPA SMA Negeri 3 Makassar yang berjumlah 226 orang. Kelas XI IPA 3 sebagai kelas eksperimen dengan 38 orang dan XI IPA 7 sebagai kelas kontrol dengan 32 orang. Defenisi operasional variable Kemampuan berpikir kritis merupakan kemampuan untuk menganalisis dan berpikir secara terorganisir berdasarkan informasi yang diperoleh dengan tujuan untuk mengambil suatu kesimpulan atau memecahkan masalah. Teknik analisis yang digunakan adalah statistic deskriptif dan analisis inferensial, berupa uji normalitas, uji homogenitas dan uji hipotesis. Adapun tahapan analisisnya adalah sebagai berikut: (1) Menentukan skor kemampuan berpikir kritis peserta didik dan (2) Menguji hipotesis dengan melakukan pengujian dasar yaitu uji normalitas dan uji homogenitas.

Data yang telah didapat dari hasil analisis data berupa lembar observasi kemudian dikonversikan dalam kategori nilai persentase dan dapat dilihat pada tabel 1.

Tabel 1. Kategori Tingkat Kemampuan Berpikir Kritis

\begin{tabular}{cc}
\hline Persentase (\%) & Kategori \\
\hline $\mathbf{8 1}-\mathbf{1 0 0}$ & Sangat baik \\
$\mathbf{6 1}-\mathbf{8 0}$ & Baik \\
$\mathbf{4 1}-\mathbf{6 0}$ & Cukup \\
$\mathbf{2 1}-\mathbf{4 0}$ & Kurang \\
$\mathbf{0 - 2 0}$ & Sangat Kurang \\
\hline
\end{tabular}

\section{HASIL DAN PEMBAHASAN}

Observasi dilakukan terhadap 38 peserta didik di kelas eksperimen dan 32 peserta didik di kelas kontrol. Berdasarkan data yang diperoleh, skor rata-rata kemampuan berpikir kritis peserta didik di kelas eksperimen berada pada kategori sedang, sementara di kelas kontrol berada pada kategori rendah.

Indikator Kemampuan Berpikir Kritis yang diukur pada observasi ini adalah interpretasi, analisis dan inferensi. Hasil penilaian tes tersebut dapat dilihat pada tabel 2.

Tabel 2. Skor Rata-rata Setiap Indikator Kemampuan Berpikir Kritis Peserta Didik

\begin{tabular}{ccccc}
\hline \multirow{2}{*}{ Indikator } & \multicolumn{2}{c}{ Eksperimen } & \multicolumn{2}{c}{ Kontrol } \\
\cline { 2 - 5 } & $\begin{array}{c}\text { Rata- } \\
\text { Rata }\end{array}$ & $\begin{array}{c}\text { Persentase } \\
(\%)\end{array}$ & $\begin{array}{c}\text { Rata- } \\
\text { Rata }\end{array}$ & $\begin{array}{c}\text { Persentase } \\
(\%)\end{array}$ \\
\hline Interpretasi & 3,1 & 42,5 & 2,3 & 53,0 \\
Analisis & 3,5 & 48,0 & 1,7 & 38,6 \\
Inferensi & 0,7 & 9,5 & 0,4 & 8,4 \\
\hline
\end{tabular}

Data yang diperoleh pada hasil observasi ini memperlihatkan bahwa dari skor rata-rata yang diperoleh peserta didik di kelas eksperimen, $42,5 \%$ adalah soal interpretasi, $48 \%$ adalah soal analisis 
dan 9,5\% merupakan soal inferensi. Sementara skor rata-rata yang diperoleh peserta didik di kelas kontrol, 53\% merupakan interpretasi, 38,6\% analisis dan 8,4\% merupakan inferensi.

\section{a. Pembahasan}

Penelitian ini dimaksudkan untuk memperoleh gambaran kemampuan berpikir kritis peserta didik kelas XI IPA SMA Negeri 3 Makassar Tahun Ajaran 2017/2018 dan mengetahui apakah terdapat perbedaan kemampuan berpikir kritis peserta didik antara kelas yang diajar dengan menggunakan metode problem solving dengan kelas yang diajar dengan menggunakan metode konvensional. Untuk mengetahui perbedaannya, diambil dua kelas sebagai kelompok sampel yaitu kelas eksperimen dan kelas kontrol. Masing-masing kelas diberi perlakuan yang berbeda.

Pelaksanaan pembelajaran pada kelas kontrol, peneliti memberikan penjabaran materi disertai dengan latihan soal yang dikerjakan oleh peserta didik. Selama proses pembelajaran berlangsung, hanya beberapa peserta didik yang serius dalam menyimak materi yang dipaparkan dan juga mengerjakan soal latihan yang diberikan. Hal ini terlihat dari hanya sedikitnya peserta didik yang mampu mengerjakan sendiri latihan soal tersebut sementara peserta didik yang lainnya hanya berharap jawaban pada temannya. Inilah alasan kurangnya peserta didik yang mampu mengerjakan soal-soal dalam bentuk tes.

Sementara di kelas eksperimen, peneliti yang menerapkan metode problem solving mendapatkan hasil yang berbeda pada hasil tesnya walaupun tidak begitu mencolok perbedaan antara keduanya. Perbedaan tersebut dapat terjadi karena pelaksanaan pembelajaran di kelas eksperimen lebih terakomodir dengan baik. Pengelompokan peserta didik ke dalam beberapa kelompok dan masingmasing kelompok diharuskan untuk berdiskusi dalam memecahkan persoalan merupakan salah satu alasan peserta didik lebih mudah diakomodir dan lebih aktif dalam belajar. Selain itu, kelompok yang merasa kesulitan mendapat bantuan oleh peneliti, dimana peneliti mengarahkan peserta didik tersebut dalam berpikir.

Indikator kemampuan berpikir kritis yang diukur pada penelitian ini adalah interpretasi, analisis dan inferensi. Hasil analisis setiap indikator kemampuan berpikir kritis di kelas eksperimen dan kelas kontrol menunjukkan perbedaan yang signifikan. Persentase skor rata-rata yang diperoleh di kelas eksperimen dan kelas kontrol untuk indikator interpretasi adalah 42,5\% dan 53,0\%, untuk indikator analisis adalah $48,0 \%$ dan $38,6 \%$ dan untuk indikator inferensi adalah 9,5\% dan 8,4\%. Berdasarkan hasil di atas, terlihat bahwa persentase skor rata-rata yang diperoleh peserta didik di kelas eksperimen lebih tinggi dibandingkan dengan persentase skor rata-rata yang diperoleh peserta didik di kelas kontrol. Kurangnya kemampuan berpikir kritis peserta didik di kelas kontrol diakibatkan karena pada saat pembelajaran berlangsung masih banyak peserta didik yang kurang paham dalam membaca dan memaknai grafik, mengidentifikasi dan menganalisis soal serta kurangnya kemampuan peserta didik dalam menarik kesimpulan dari data-data yang diberikan.

Berdasarkan hasil analisis deskriptif kemampuan berpikir kritis peserta didik pada distribusi frekuensi dan persentase rata-rata skor kemampuan berpikir kritis diperoleh bahwa skor rata-rata peserta didik kelas eksperimen berada pada kategori sedang dengan persentase 73,7\%. Sedangkan untuk kelas kontrol skor rata-rata peserta didik berada pada kategori rendah dengan persentase $62,5 \%$. Hal tersebut menunjukkan bahwa skor rata-rata kelas eksperimen yang diajar dengan menggunakan metode problem solving lebih tinggi daripada skor rata-rata kelas kontrol yang diajar dengan menggunakan metode konvensional. 
Penelitian ini sejalan dengan penelitian yang dilakukan oleh Septi Ayuningsih dalam penelitiannya yang berjudul Pengaruh Penggunaan Metode Pembelajaran Problem Solving terhadap Kemampuan Berpikir Kreatif Matematika Siswa SMA Handayani Pekanbaru. Pada penelitiannya, Septi Ayuningsih memperoleh hasil yang sama seperti penelitian ini dan kemudian menyimpulkan bahwa metode problem solving memiliki pengaruh positif terhadap kemampuan berpikir peserta didik. Hal ini disebabkan karena dalam pembelajaran di kelas siswa dikelompokkan ke dalam beberapa kelompok sehingga siswa lebih bisa berinteraksi satu sama lainnya. Di sisi lain juga siswa lebih mudah untuk diamati (Ayuningsih, 2013).

Diluar dari masih kurangnya kemampuan berpikir kritis peseta didik tersebut, metode problem solving yang diterapkan di kelas dapat menghasilkan perbedaan dibandingkan dengan hanya menggunakan metode pembelajaran konvensional di kelas seperti biasanya. Perbedaan hasil analisis deskriptif kelas eksperimen dan kelas kontrol ini dapat terjadi karena dalam proses pembelajaran dengan menggunakan metode problem solving, peserta didik tampak bersemangat dalam mencari dan menemukan solusi penyelesaian masalah. Peserta didik juga aktif dalam bertanya dan percaya diri dalam mempresentasikan hasil diskusi yang telah mereka selesaikan bersama.

Hasil perhitungan analisis inferensial menunjukkan bahwa skor kemampuan berpikir kritis peserta didik di kelas XI IPA SMA Negeri 3 Makassar antara kelas eksperimen dan kontrol berdistribusi normal dan memiliki varians yang homogen sehingga prasyarat penggunaan uji-t terpenuhi. Dalam pengujian hipotesis dengan menggunakan uji-t, pada kemampuan berpikir kritis memperlihatkan bahwa $\mathrm{H}_{0}$ ditolak dan $\mathrm{H}_{1}$ diterima yang menunjukkan bahwa terdapat perbedaan yang signifikan terhadap kemampuan berpikir kritis antara peserta didik yang diajar menggunakan metode problem solving dengan peserta didik yang diajar menggunakan metode konvensional.

Berdasarkan uraian di atas, maka dapat dikemukakan bahwa metode problem solving memiliki peranan yang cukup berarti sehingga dapat membantu peserta didik dalam memahami, menganalisis dan menyelesaikan permasalahan fisika dengan tepat dan pada akhirnya dapat meningkatkan kemampuan berpikir kritis peserta didik, khususnya peserta didik kelas XI IPA SMA Negeri 3 Makassar.

\section{KESIMPULAN}

Berdasarkan hasil penelitian dan pembahasan dapat disimpulkan sebagai berikut.

1. Kemampuan berpikir kritis peserta didik kelas XI SMA Negeri 3 Makassar yang diajar menggunakan metode problem solving berada pada kategori sedang.

2. Kemampuan berpikir kritis peserta didik kelas XI SMA Negeri 3 Makassar yang diajar dengan menggunakan metode konvensional berada pada kategori rendah.

3. Terdapat perbedaan kemampuan berpikir kritis yang signifikan antara peserta didik yang diajar menggunakan metode problem solving dengan peserta didik yang diajar menggunakan metode konvensional kelas XI SMA Negeri 3 Makassar tahun ajaran 2017/2018.

\section{REFERENSI}

Aminah, S. (2012). Implementasi Strategi Probing Prompting dan Time Token dalam Pembelajaran Biologi terhadap Hasil Belajar Siswa Kelas VIII Semester Genap SMP Negeri 2 Mojogedang Tahun Ajaran 2011/2012. Surakarta: Universitas Muhammadiyah Surakarta. 
Ayuningsih. (2013). Pengaruh Penggunaan Metode Pembelajaran Problem Solving terhadap Kemampuan Berpikir Kreatif Matematika Siswa SMA Handayani Pekanbaru. Pekanbaru: Universitas Islam Negeri Sultan Syarif Kasim Riau.

Fajar, M. F. (2014). Pengaruh Metode Pembelajaran Tanya Jawab Probing Prompting terhadap Hasil Belajar Siswa pada Standar Kompetensi Menerapkan Dasar-dasar Elektronika Kelas X AV Di SMK Negeri 2 Surabaya. Jurnal Pendidikan Teknik Elektro, Volume 03, 89-96.

Hamiyah, N. (2014). Strategi Belajar Mengajar di Kelas. Jakarta: Prestasi Pustaka Publisher.

Permendikbud. (2014). Kurikulum 2013 Sekolah Menengah Atas/Madrasah Aliyah No. 59 Tahun 2014. Jakarta: Permendikbud.

Rahmah, A. (2015). Penerapan Model Pembelajaran Inkuiri Terbimbing untuk Meningkatkan Keterampilan Berpikir Kritis Siswa pada Pokok Bahasan Ekosistem Kelas X Di SMA Negeri 1 Krangkeng. Scientiae Educatiae, Volume 4 Edisi 1.

Syofyan, H. (2016). Penerapan Metode Problem Solving pada Pembelajaran IPA untuk Peningkatan Kemampuan Berpikir Kritis. Unisbank Semarang, 966-976.

Tawil, M. (2013). Berpikir Kompleks dan Implementasinya dalam Pembelajaran IPA. Makassar: Badan Penerbit UNM.

Yustina, S. (2015). Penerapan Metode Pembelajaran Problem Solving terhadap Kemampuan Berpikir Kritis Siswa pada Materi Koloid Kelas XI IPA SMA Negeri 4 Banjarmasin. QUANTUM, Jurnal Inovasi Pendidikan Sains, Vol. 6 No. 2, 108-117. 